\title{
Erratum to: Experimental Investigation and Thermodynamic Modeling of the Ni-Rich Part of the Ni-N Phase Diagram
}

\author{
MATEJ FONOVIĆ, ANDREAS LEINEWEBER, and ERIC J. MITTEMEIJER
}

DOI: $10.1007 / \mathrm{s} 11661-015-2858-8$

(C) The Minerals, Metals \& Materials Society and ASM International 2015

Erratum to: METALLURGICAL AND MATERIALS

TRANSACTIONS A, VOLUME 45A,

OCTOBER 2014, pp. 4863-4874

DOI: $10.1007 / \mathrm{s} 11661-014-2440-9$

IN the published article the double arrows inadvertently disappeared from Eqs. [4], [10], and [15]. Following are the corrected equations:

$$
\begin{gathered}
\frac{1}{2} \mathrm{~N}_{2} \rightleftarrows[\mathrm{N}] . \\
\mathrm{NH}_{3} \rightleftarrows[\mathrm{N}]+\frac{3}{2} \mathrm{H}_{2} . \\
\mathrm{NH}_{3} \rightleftarrows \frac{1}{2} \mathrm{~N}_{2}+\frac{3}{2} \mathrm{H}_{2} .
\end{gathered}
$$

MATEJ FONOVIĆ, Ph.D. Student, and ANDREAS LEINEWEBER, Research Scientist, are with the Max Planck Institute for Intelligent Systems (formerly Max Planck Institute for Metals Research), Heisenbergstraße 3, 70569 Stuttgart, Germany. Contact e-mail: a.leineweber@is.mpg.de ERIC J. MITTEMEIJER, Director, is with the Max Planck Institute for Intelligent Systems (formerly Max Planck Institute for Metals Research), and Professor, at the Institute for Materials Science, University of Stuttgart, Heisenbergstraße 3, 70569 Stuttgart, Germany.

The online version of the original article can be found under doi:10.1007/s11661-014-2440-9.

Article published online March 28, 2015 